\title{
ДЕРЖАВОТВОРЧІ ФУНКЦІї ПУБЛІЦИСТИКИ ВОЛОДИМИРА ЗДОРОВЕГИ
}

\author{
Мирослава Рудик \\ Львівський національний університет імені Івана Франка, \\ вул. Генерала Чупринки, 49, 79044, Львів, Україна, \\ e-mail: journft@,franko.lviv.ua
}

У статті досліджено роль Володимира Здоровеги, багаторічного декана факультету журналістики Львівського національного університету імені Івана Франка у державотворчих процесах. Визначено державотворчі функції публіцистики вченого. Досліджено еволюцію політичної публіцистики Володимира Здоровеги:від критики тоталітаризму до націєтворчих концептів.

Ключові слова: Володимир Здоровега, публіцистика, державотворення.

Актуальність досліджуваної теми зумовлена потребою дослідження державотворчого змісту публіцистики Володимира Здоровеги. Адже за допомогою публіцистичного слова вчений намагався консолідувати суспільство за допомогою націєтворчих концептів доводив утопічність радянської ідеології, розвінчував злочини комуністичної влади.

Історіографія питання. Публіцистичну спадщину Володимира Здоровеги досліджували О. Кузнецова, I. Михайлин, І. Павлюк, І. Паславський, М. Присяжний. Але участь Володимира Здоровеги у процесах державотворення не була відображена у журналістикознавчих розвідках.

Мета нашого дослідження - дослідити державотворчі функції публіцистики Володимира Здоровеги, окреслити роль вченого у переході факультету журналістики на україноцентричні рейки.

Ми ставимо перед собою завдання:

- дослідити публіцистичні праці Володимира Здоровеги;

- визначити державотворчі функції публіцистики вченого;

- простежити еволюцію політичної публіцистики Володимира Здоровеги;

- окреслити значення поглядів Володимира Здоровеги для розвитку української журналістики.

Об’єктом нашого дослідження є публіцистичні матеріали Володимира Здоровеги.

Предмет дослідження - ідейно-змістові особливості публіцистики Володимира Здоровеги.

(C) Рудик М., 2018 
Новизна нашого дослідження полягає в тому, що публіцистична спадщина В.Й. Здоровеги ще не достатньо вивчена журналістикознавцями і потребує комплексного дослідження з погляду ідейного змісту та державотворчих функцій.

Період незалежності України став етапом розвитку національної проблематики у творчості Володимира Здоровеги. Саме у цей час відбувається ідейна трансформація його суспільно-політичних поглядів. Зважаючи на це, важливим є вивчення державотворчого змісту публіцистики Володимира Здоровеги, що допоможе краще зрозуміти особливості політичного дискурсу незалежної України. Вважаємо, що державотворчий зміст - одна з домінуючих рис публіцистики Володимира Здоровеги. На початковому етапі державотворення простежуємо активну позицію вченого, що знайшла своє відображення як в науково-педагогічній, так і в публіцистичній творчості.

М. Присяжний зазначає: «Останніми роками Володимир Здоровега багато писав, його статті з'являлися чи не щотижня в газетах «Дзеркало тижня», «День», «Високий замок». Він ніби спішив поділитися з читачами своїм багатим досвідом, дати оцінку явищам і процесам, які відбуваються у політичному, культурному, економічному житті незалежної України. Особливо турбували вченого, публіциста справи у нашому журналістському цеху, на інформаційному ринку України, у сфері підготовки майбутніх кадрів для ЗМІ. Володимир Здоровега чітко простежував виклики перших років XXI століття щодо журналістики і намагався сформулювати відповіді на них. Частина публікацій склали книгу «Про журналістику і журналістів», яка сьогодні використовується на факультеті як своєрідний посібник для студентів. Він не стояв би осторонь і зараз, коли майже щодня помічаємо негаразди у власному журналістському середовищі» [13, с. 59].

Однак, як слушно зауважує професор ЛНУ ім. І. Франка В. В. Лизанчук, «щоби справедливо назвати «комуністичний рай» «сущим пеклом», Володимиру Йосиповичу довелося складати не один суспільно-політичний іспит» [12]. Будучи деканом факультету журналістики, Володимир Здоровега неодноразово отримував звинувачення за свій лібералізм у ставленні до студентів, який тоталітарна система трактувала як вседозволеність і забавку у демократію. Чого тільки вартувало викриття рукописного самвидаву «Лєсная правда» у 1981 році?! Це було нелегке випробування для факультету журналістики - відрахували студентів, залякували на допитах викладачів. Студентська «Лєсная правда» містила укладену абетку патріотичного спрямування, де, наприклад, на літеру «С» був Сибір. Також у рукописі були дотепні висловлювання про лідерів тогочасної партійної системи, віршовані рядки про москалів, іронічно-саркастична оцінка «світлого» соціалістичного життя. Наступним ворогом комуністичної ідеології стала настінна газета «Точка зору». Це видання було популярним завдяки свіжості думки, неординарності поглядів на політичні події, що суперечили офіційним настановам компартії. Володимир Здоровега мужньо відстоював своїх студентів, розуміючи штучність і безперспективність радянської концепції.

Декан В. Здоровега з колективом викладачів намагалися прищепити студентам любов до істини, до рідного слова. Зокрема, 1988 року у Львові було створено Товариство української мови імені Тараса Шевченка, головою якого став письменник Роман Іваничук. Цікавим є те, що перший осередок цього Товариства у Львівському університеті був створений при «ідеологічному» факультеті журналістики. Промо- 
вистим фактом на користь українізації є колективна заява деканів різних факультетів Львівського університету про їхній вихід з КПРС, що була опублікована 1990 року. В. Лизанчук зазначає; «Нині цей факт декому може здатися пересічним. Насправді - це був мужній вчинок, адже кинуто виклик комуністичній тоталітарній системі. Текст цієї заяви писав В. Й. Здоровега» [12].

Володимир Здоровега завжди намагався шукати компроміс, навіть там, де здавалося, він $є$ неможливим. Критично сприймав своє життя і радянську дійсність, переосмислював свої погляди і вчинки, мав велику мужність визнати свої помилки і попросити пробачення у скривджених його словом, що, на нашу думку, свідчить про його громадянську позицію.

Діяльність вченого і публіциста у період здобуття Україною незалежності - це щоденна клопітка праця, участь у державотворчих процесах в Україні за допомогою навчання студентів-журналістів, видання відповідної навчальної літератури, гострих публіцистичних виступів у ЗМІ та громадської роботи. Володимир Здоровега критично сприймав радянську дійсність, розуміючи усю складність тоталітарної системи. Ніколи не був фанатом комуністичної ідеології. Коли вченого питали «що Ви робили, коли ми сиділи в тюрмах?», він скромно відповідав: «Вчив студентів писати правду».

Професор О. Кузнецова зауважує: «Він не був бунтарем, опозиціонером, дисидентом... Своїм засобом для досягнення мети обрав публіцистичне слово, що $\epsilon$ завжди опозиційним, переконливим до офіційної, владної позиції. Він усвідомлював силу тогочасного режиму, й чітко розумів, що сильнішою може бути тільки сила прозрілого народу, якому набридне демагогія і лицемірство» [11, с. 174]. Ця цитата якнайповніше виражає значення публіцистики Володимира Здоровеги для українського суспільства і сповна характеризує вченого, педагога, публіциста, який ще у радянські часи готував фундамент для становлення демократії.

У час дефіциту нового мислення, в умовах, коли суспільство перебуває у стані невизначеності, коли політики не можуть визначитися щодо національної ідеї, політична еліта не здатна згуртувати народ, зростає роль публіцистики, яка бере на себе місію розкриття сутності нашого минулого і консолідації суспільства навколо національних інтересів. За допомогою публіцистичного слова розвінчуються ідеологічні міфи, усуваються історичні прогалини, відкривається пріоритет правди.

Як публіцист Володимир Здоровега брав активну участь у становленні української державності. Його публіцистична спадщина відображає складний процес державотворення. У своїх публікаціях автор дає оцінку політичному вектору розвитку країни.

Місію своїх публіцистичних виступів Володимир Здоровега бачив у формуванні нової особистості, нового типу мислення на основі досвіду попередніх поколінь 3 візією у майбутнє. На наш погляд, його публіцистичні статті на суспільно-політичну тематику заслуговують на увагу як медіа-дослідників, так і широкої аудиторії хоча б тому, що в них наведено виразні приклади передбачення політичних подій та думки, що об’єктивно пояснюють хід розвитку країни. Публіцистична спадщина Володимира Здоровеги на зламі епох характеризується світоглядністю, глибиною i масштабністю мислення, гуманістичними ідеями та прогностичним потенціалом. Осмислюючи його публіцистичну творчість, звертаємо увагу на відображення у ній особистості автора. У своїх публікаціях Володимир Здоровега зосереджує увагу на 
важливих проблемах і визначає шляхи їх розв'язання. Серед перешкод на шляху державотворення виділяе такі:

- створення фальшивих історичних стереотипів, маніпуляція громадською думкою;

- проблема моральності, що загрожує занепадом суспільства, руйнуванням людської особистості;

- проблема функціонування мови як державотворчої категорії;

- проблема перекваліфікації 3МІ з тоталітарних на демократичні;

- відсутність національної політичної еліти.

У статтях, які були написані на початку 90-х років XX століття, Володимир Здоровега не лише оперативно відгукується про наболілі питання суспільно-політичного життя, його публіцистика виконує просвітницьку функцію щодо національного питання, культурного розвитку, визначення історичної правди й утвердження духовних та моральних цінностей.

У публікаціях Володимира Здоровеги простежуємо тенденції патріотизму, гуманізму, моралізму, естетизму, творення нової демократичної культури. Публіцистика Володимира Здоровеги сприяла розвиткові процесів національного самоутвердження. Публіцист повною мірою активізував свою візію національної ідентичності через призму політики і культури, які становлять два основні напрямки формування нації. Уже на п’ятому році незалежності України Володимир Здоровега, відчувши вимогу часу, звертає увагу на необхідність офіційного державного визнання воїнів ОУН-УПА воюючою стороною у роки Другої світової війни. Адже «без них, без ОУН-УПА, без в'язнів сумління не змогла б утвердитися сама ідея суверенності. I то не було явищем локальним, скажімо, галицьким, хоч найбільші імпульси національного волевияву струмували звідси» [3].

У публікаціях «Сповідь на вершині життя про те, як з хохлів стають українцями», «Ми довели, що дозріли», «Собі і людям», «Росія очима українця: стратегічний партнер чи...?», «Хай святиться ім'я твоє», які підсумовують п’ятиріччя української незалежності, Володимир Здоровега реалізує механізм державотворення через усвідомлення історичних реалій та подолання тавра бездержавності. «Мусимо позбутися тавра гомо совєтікуса, яке носять практично всі народи, що вилупились із загальносоюзного колгоспу» [8], - зазначає автор.

Володимир Здоровега розвінчує стан ейфорії після проголошення незалежності України, наголошуючи на потребі доведення своєї політичної зрілості невтомною працею, здобутками в науці, мистецтві, економіці: «Романтичні мрії, коли багатьом вірилось, що досить проголосити незалежність, як автоматично у хату прийде достаток і добробут, залишились у минулому... Потрібна праця, мудрість, чесність, діяльна робота» [8].

У його публіцистиці знайшло відображення і прийняття Конституції України (1996). Публіцист вважає їі видатним історичним документом, хартією нашої доби. Хоч Конституція і не позбавлена недоліків, однак законодавчо утверджує процес державотворення. Володимир Здоровега звертає увагу на правові аспекти, які мають декларативний характер: «Україна в цьому плані унікальна. Зважаючи на історичні причини та особливості свого міжнародного становища, вона змушена захищати національну гідність, право на рідну мову і культуру. Без протекціонізму, без пріо- 
ритетів до рангу закону нам не обійтись. Тут потрібна зважена, продумана державна воля, приведення конкретних реалій у відповідність до вимог Конституції» [2].

Державотворчі мотиви наявні у статті Володимира Здоровеги «Чи український наш інформаційний простір?» [10], де публіцист б’є на сполох через експансію інформаційного ринку російськомовною літературою і періодикою. «Очевидною $є$ необхідність правового захисту національного інформаційного простору» [10], - наголошує В. Здоровега. Адже інформаційна політика $є$ важливою стратегією у міжнародних зв'язках України, бо «інформаційний простір держави сягає настільки далеко, наскільки вона може закинути власну інформацію у світ» [10]. Однак Україна через економічні чинники та відсутність державної політики, на жаль, не репрезентує себе належним чином у світі. Публіцист ставить питання гостро: «Або ми матимемо його [інформаційний простір - M. P.] українським за змістом і формою, або свідомістю і поведінкою громадян України управлятимуть інші сили» [10]. Це застереження було виправданим, адже незахищеність національного інформаційного простору спричинила ворожі впливи Росії на свідомість громадян східного регіону України.

Актуальним завданням публіцистики Володимира Здоровеги було відображення повноти життя. Саме тому у своїх матеріалах він комплексно підходить до висвітлення проблем національного характеру, нашаровуючи різні пласти духовно-інтелектуальної сфери. Акцентує на толерантності в ім'я національної згоди, готовності до компромісу, консолідації суспільства навколо гуманістичних ідей, на основі чого твориться колективна національна ідентичність. Його боліла проблема поділу України на захід і схід, що є особливо актуальним у наш час, коли, Україна втягнута у стан війни. Переконливим $є$ судження Володимира Здоровеги: «Саме це тавро бездержавності, а точніше, довголітнє буття під владою різних чужих держав породило недовіру між собою, умовно кажучи східного і західного регіонів, на якій так спекулювали вороги України» [8]. Володимир Здоровега наголошував на цій проблемі, яка сьогодні набула масштабного концептуального значення, бо український ворог знову скористався нашою слабинкою. Він виправдовує ментальність українців східного регіону: «Багато цих людей, особливо, на сході України, ображаються, коли чують несправедливі, іноді необачно кинуті на їх адресу слова зневаги. Вони не винні у тому, що їх постійно обманювали, визискували, зневажали і переслідували, гноїли у тюрмах, зрештою знищували як націю, як народ» [8]. Сьогодні це судження надзвичайно актуальне. Ситуація на сході України є результатом програної інформаційної політики держави, відсутністю національної ідеології.

Помаранчева революція також була осмислена публіцистом як самостверджувальний чинник української нації. Щодо змін, які принесла Помаранчева революція у журналістику, то Володимир Здоровега коментує їх так: «Під час Помаранчевої революції ми вибороли право на свободу слова. Сталося так, що багато журналістів під час цих подій відмовилися служити певним інтересам... Таки чином ми продемонстрували світові, що українська журналістика в певний період була найдемократичнішою у світі» [9].

Сьогоднішній і завтрашній день української журналістики Володимир Здоровега пов'язує насамперед із формуванням національних кадрів журналістів-професіоналів. Журналіст, на його думку, має бути «переконаним патріотом, людиною християнської моралі, гуманних поглядів. Він повинен уміти глибоко мислити, самостійно аналізувати, точно передавати факти і сміливо відстоювати правду і спра- 
ведливість... Це людина високої культури, знавець і популяризатор рідної мови. Виховувати таких журналістів-професіоналів не можна, не враховуючи досвід наших попередників, у свій час заборонених і невідомих навіть фахівцям у галузі журналістики» [6, с. 21-22]. Такими фахівцями В. Здоровега вважає М. Грушевського, Д. Донцова, С. Петлюру, С. Бандеру, В. Винниченка, І. Багряного та багатьох інших діячів українського національно-визвольного руху. Зазначає: «Ми вважаємо, що їх спадщина для формування професіоналізму сучасного українського журналіста важить більше, ніж відкинуті самим життям догми і постулати тоталітарної преси» [6, c. 21-22].

Публікація «Європейський вибір: що брати з минулого, а чого вчитися українським ЗМІ» [2] висвітлює історичні умови формування української журналістики. Володимир Здоровега зазначає: «Україна успадкувала від Союзу провінційну інформаційну інфраструктуру й кадри, здатні лише до провінційного, а не державного мислення» [2]. 3 огляду на це, «щоб сформувати професіоналів, треба, спираючись на власний національний досвід, навчаючись на зразках високоякісної західної журналістики, моделювати еталони журналістської майстерності, ставлячи на перший план компетентність, здатність журналіста проникати в суть життєвих проблем, моральність, мужність і вміння говорити правду» [2]. Володимир Здоровега зазначає: «Ми маємо не гірших, ніж на Заході, журналістів. Це загальна думка європейських експертів. Але немає економічних, правових та організаційних умов їхнього творчого зростання» [2].

На підставі проаналізованих публікацій Володимира Здоровеги можемо стверджувати: він розумів, що успішне функціонування ЗМІ можливе лише у комплексі із загальнодержавними гарантіями. Журналістська діяльність безпосередньо залежить від державотворчих чинників. Публіцист розглядав журналістику не ізольовано від державних проблем, а вважав її предметом відображення реальності. Це підтверджує правдиве судження Володимира Здоровеги про те, що у бідній країні не буває багатих мас-медій: «Однією з трагічних помилок лідерів українського національно-визвольного руху було те, що питання соціальні, питання власності на землю, на заводи і фабрики відклалися на другий, якщо не на десятий план» [4].

Публіцистика Володимира Здоровеги є віддзеркаленням складних моментів державотворчого процесу, насамперед самовизначення українців. Публіцист застерігає від створення хибного образу України, «конструювання такого собі українсько-російського гібриду» [4].

Хвилювало Володимира Здоровегу й ідейне наповнення інформаційного простору: «Нам сьогодні дуже бракує кваліфікованої проповіді державотворчих, демократичних ідей. Слава Богу, маємо хоча б якусь дещицю правдивих, талановитих публіцистів на радіо, в інтернетівських виданнях, у періодиці, чого, на жаль, не скажеш про телебачення» [7].

У інтерв’ю в тижневику «Без цензури» Володимир Здоровега окреслив своє бачення майбутнього української журналістики, хоча і вважав, що прогнозувати його дуже небезпечно. На його думку, «українська журналістика в основі своїй має бути українською, українською за духом» [9]. Другий аспект, який виділяє публіцист, - це шанобливе ставлення до української мови і гарантування її розвитку як державної: «Державна мова має бути державною. Я зовсім не проти російської мови і не думаю, що її хтось знищуватиме. Я щасливий з того, що можу нею писати й читати. Це мене 
збагачує. Але я за українську. Нею мусять послуговуватися держслужбовці та ЗМІ» [9]. Третім завданням української журналістики вважав встановлення у суспільстві політичної та інформаційної культури: «Журналістика матиме авторитет, коли вона буде не лише чесно та всебічно інформувати, а й коли вона буде чесно критикувати, полемізувати й, бажано, прогнозувати. Мені хочеться вірити, що через десять років українська журналістика стане значно якіснішою і з нашим специфічним національним колоритом, бажано без шароварщини. Європейські ЗМІ стали дуже подібними, тому хочеться, щоб українська журналістика мала якийсь національний колорит, завдяки якому її впізнаватимуть» [9].

Власне на ЗМІ публіцист покладає велику відповідальність за державний поступ. Зміна геополітичного вектора на користь європейського майбутнього нашої держави є одночасною потребою відмежування українців від росіян, звільнення від контролю «старшого брата». Про «демократичну Росію» Володимир Здоровега висловлюється так: «Демократична - це коли стирати 3 лиця землі Чечню, це коли кожного, хто проти, «мочить в сортире»? Це коли так тиснути у братніх обіймах, щоб аж запищали і попросилися, як керівник близької нам Білорусії, до спільного казана? Навіть спільного казана уже не буде. Казан спорожнів і був поділений старшим братом за принципом: «Это мне, это мне, это тоже мне...» [4]. У цих словах бачимо пророчий зміст захланно-загарбницької політики Росії, результатом діянь якої ми втратили Крим і кров’ю захищаємо Донбас.

Мотиви державотворення також наявні у публіцистиці Володимира Здоровеги про духовних велетів української нації - Тараса Шевченка та Івана Франка. Важливим у процесі державотворення $є$ узагальнення історичної та культурної спадщини народу через творчість письмеників, художників, діячів культури. У низці публікацій Володимир Здоровега утверджує національну ідентичність за допомогою творчого і життєвого шляху окремих особистостей. Ці нариси мозаїчно становлять духовну спадщину українського народу, естетичну цінність, порушують чимало моральних та етичних проблем, сприяють яскравому відображенню самовизначення нації, є наочним прикладом того, що ідея української державності продовжувала жити у свідомості українців навіть у часи пригноблення.

Публіцистика Володимира Здоровеги є важливою складовою системи розкриття сутності нашого минулого, пошуком національної ідентичності, шляхом переміни посттоталітарного суспільства в націю. Першою функцією публіцистики Володимира Здоровеги у реалізації державотворчих процесів $є$ пригадати героїчне минуле, високу культуру та освіченість народу, його моральні якості. Його публіцистика спрямована на духовне самовизначення нації, звернення до етичних та моральних проблем тогочасної дійсності. Україноцентричні ідеї публіцистики Володимира Здоровеги становлять цілісну концепцію української політично незалежної нації. Публіцист формулює завдання преси та акцентує на важливості питання свободи слова як основного чинника участі ЗМІ у процесах державотворення в демократичному суспільстві, на потребі створення єдиного інформаційно-комунікаційного простору для пропагування ідей національної ідентичності, формування громадської думки. Порушує одвічну проблему ментальності українців у контексті геополітичної орієнтації, визначаючись на користь європейського майбутнього. Вважає українців європейцями не лише за територіальним принципом, а насамперед за культурним і духовним. Вдається до екскурсу в минуле: «Європейські злети України припадають на ті моменти істо- 
piї, коли журналістики, навіть у найширшому тлумаченні цього слова, не було або вона перебувала у зародковому стані (епоха Київської Русі, Хмельниччина з їхньою високою літописною культурою, ораторською прозою, полемічною публіцистикою» [5, с. 40]. Однак питання європейського вибору у публіцистиці Володимира Здоровеги більше має внутрішньополітичний характер.

Державотворчі функції публіцистики Володимира Здоровеги реалізовано через призму політичної та культурної проблематики. Адже політика і культурна сфера, до якої належать і 3MI, через широке коло зацікавлення активно залучають маси до державотворчих процесів. У цій візії Володимир Здоровега наближається до поглядів Івана Франка, який проект української незалежної нації вбачав у політичній соціалізації та консолідації народу навколо національної культури.

\section{REFERENCES}

1. Здоровега В. Без консолідації і професіоналізму не вижити // Про журналістику і журналістів: Статті, есе, виступи діалоги / Володимир Здоровега. - Львів : Видавничий центр ЛНУ імені Івана Франка, 2004. - С. 20-29.

2. Здоровега В. Свропейський вибір: що брати з собою, а чого вчитися українським 3МІ // Про журналістику і журналістів: Статті, есе, виступи діалоги / Володимир Здоровега. - Львів : Видавничий центр ЛНУ імені Івана Франка, 2004. - С. 39-44.

3. Здоровега В. Ми довели, що дозріли / Володимир Здоровега // Високий Замок. 1996. - 23 серп.

4. Здоровега В. Не сотвори собі гомункулуса / Володимир Здоровега // День. - 2001. 18 трав.

5. Здоровега В. Про журналістику і журналістів: статті, есе, виступи, діалоги / В. Здоровега. - Львів: Видавничий центр ЛНУ імені Івана Франка, 2004.- 133c.

6. Здоровега В. Професіоналізм українського журналіста у контексті історичного досвіду та сучасних економіко-політичних реалій / Володимир Здоровега // Українська періодика: історія і сучасність : Тези доп. і повід. Всеукр. наук.-теорет. конф. - Л., 1999. - С. 12-22. (Львів, 9-10 груд. 1998 р.) ; [за ред. М. М. Романюка]. Львів, 1999. - С. 12-22.

7. Здоровега В. Сила і безсилля слова / Володимир Здоровега // Дзеркало тижня. 2002. - 7 верес.

8. Здоровега В. Хай святиться ім'я твоє / Володимир Здоровега // Молода Галичина. - 1996. - 23 серп.

9. Здоровега В. Чим талановитіший журналіст, тим важче ним управляти [ Електронний ресурс ] / Володимир Здоровега. - Режим доступу : http://www.bezcenzury. com.ua/ru/archive/4089/4106/4107.html

10. Здоровега В. Чи український наш інформаційний простір? / Володимир Здоровега // Тиждень. - 1997. - 22 серп.

11. Кузнецова О. Український теоретик публіцистики - перший / Олена Кузнецова // Пресознавчі студії: історія, теорія, методологія : зб. праць каф. укр. преси і дослід. центру історії західноукр. преси. - Вип. 2(8). - Львів, 2007 - С. 174-177.

12. Лизанчук В. Випробування на національну свідомість / Василь Лизанчук // Журналіст України. - 2010. - № 9. - С. 30-33. 
13. Присяжний М. Володимир Здоровега на тлі доби / Михайло Присяжний // Львівська школа журналістики. Постаті / І. Лубкович, І. Паславський, М. Присяжний. Львів : ПАІС, 2014. - С. 54-61.

\title{
STATE-BUILDING FUNCTIONS OF VOLODYMYR ZDOROVEHA'S JOURNALISM
}

\author{
Myroslava Rudyk \\ Ivan Franko National University of Lviv, \\ Generala Chuprynky Str., 49, 79044, Lviv, Ukraine \\ e-mail:journft@franko.lviv.ua
}

An author probes problems, broken in a journalism and world, view tendencies of journalism of the known publicist, professor of the Ivan Franko National University of Lviv, Volodymyr Zdoroveha.

The period of independence of Ukraine became the stage of development of national issues in the Volodymyr Zdoroveha's work. The ideological transformation of his social and political views took place at that exact time. Therefore, it is important to study the state-building content of Volodymyr Zdoroveha's journalism, what will help to better understand the peculiarities of the political discourse of independent Ukraine. We consider that state-building content is one of the dominant features of Volodymyr Zdoroveha's journalism. In the initial stage of state development, we observe the active position of the scientist, which is reflected in both scientific and pedagogical work as well as in journalistic creativity.

In the time of a deficiency of new thinking, in a situation where society is in a state of uncertainty, when politicians cannot decide on a national idea, the political elite is not able to rally the people, the role of journalism is growing, which takes on the mission of disclosing the essence of our past and consolidating the society around the national interests. With the help of a journalistic word, ideological myths are deconstructed, historical flaws are eliminated, and precedence of truth is revealed.

As a journalist, Volodymyr Zdoroveha took an active part in the formation of Ukrainian statehood. His journalistic heritage reflects the complicated process of state creation. In his publications, the author assesses the political vector of the country's development.

In the articles written in the early 90s of the twentieth century, Volodymyr Zdoroveha not only promptly responds to the festering issues of sociopolitical life, but his journalism also carries out an educational function in relation to the national question, cultural development, the definition of historical truth and the affirmation of spiritual and moral values.

In Volodymyr Zdoroveha's publications, we trace the tendencies of patriotism, humanism, moralism, aestheticism, the creation of a new democratic culture. Volodymyr Zdoroveha's journalism contributed to the development of national self-affirmation processes. The publicist has fully activated his vision of national identity through the prism of politics and culture, which are two basic directions of nation-building. Volodymyr Zdorovegy's journalism is an important part of the system of revealing the essence of our past, the search for national identity, through the transformation of the post-totalitarian society into a nation. The first function of Volodymyr Zdoroveha's journalism in realizing state-building processes is to recall the heroic past, high culture and education of the people, their moral qualities. His journalism is aimed 
at the spiritual self-determination of the nation and addressing the ethical and moral problems of the then reality. Ukrainian-centered ideas of Volodymyr Zdoroveha's journalism form the integral concept of a Ukrainian politically independent nation. The journalist formulates the missions of the press and emphasizes the importance of the issue of freedom of speech as the main factor in the participation of the media in the processes of state-building in a democratic society, he insists on the need to create a united information and communication space for the propagation of ideas of national identity, the formation of public opinion. The journalist violates the eternal problem of the mentality of Ukrainians in the context of geopolitical orientation, while he is inclined to choose the model of the European future. He considers Ukrainians to be Europeans not only by territorial principle but primarily by cultural and spiritual ones.

Key words: V. Zdoroveha, Ukrainian journalism, publicism, theory, journalistic master. 